\title{
Pathotypes of Bacterial Spot Pathogen Infecting Capsicum Peppers in Korea
}

\author{
Khin Pa Pa Wai, Muhammad Irfan Siddique, Hwang-Sung Mo, Hee Ju Yoo, Si-Eun Byeon, Yoonhyuk Jegal, \\ Alebel A. Mekuriaw and Byung-Soo Kim* \\ Department of Horticultural Science, Kyungpook National University, Daegu 702-701, Korea
}

(Received on May 4, 2015; Revised on July 22, 2015; Accepted on July 23, 2015)

Sixty-seven isolates of bacterial spot pathogen (Xanthomonas spp.) collected from six provinces of Korea were tested for the identification of their pathotypes and determination of their distribution throughout Korea in an effort to genetically manage the disease. Near isogenic lines of Early Calwonder (Capsicum annuum) pepper plants carrying $B s_{1}, B s_{2}$ and $B s_{3}$, and PI235047 (C. pubescens) were used as differential hosts. Race P1 was found to be predominant, followed by race $\mathrm{P} 7$, and races $\mathrm{P3}$ and $\mathrm{P8}$ were also observed. This is the first report of races $\mathrm{P} 7$ and $\mathrm{P8}$ in Korea. The races $\mathrm{P} 7$ and P8 were differentiated from the former races $\mathrm{P1}$ and $\mathrm{P3}$, respectively, on the basis of their ability to elicit hypersensitive reactions to PI235047.

Keywords : Capsicum annuum, Capsicum pubescens, race, resistance, Xanthomonas spp.

Bacterial spot disease is one of the major diseases damaging pepper plants in Korea. This pathogen, formerly called Xanthomonas campestris pv. vesicatoria (Doidge) Dye, is currently subdivided into Xanthomonas euvesicatoria, $X$. vesicatoria, $X$. gardneri, and $X$. perforans on the basis of DNA homology and phenotypes (Hamza et al., 2010; Jones et al., 2004, 2005). However, Korean strains of the bacterial spot pathogen have not been reclassified into these four species. Although treatment of seeds with hot water or chemicals, spraying plants with chemicals including copper and antibiotics, rotation with non-host plants, and sanitation by removing volunteer plants and diseased plant residue are recommended for control of the disease

\footnotetext{
*Corresponding author.

Phone) +82-53-950-5729, FAX) +82-53-950-5722

E-mail) bskim@knu.ac.kr

This is an open access article distributed under the terms of the Creative Commons Attribution License (http://creativecommons.org/licenses/by/2.0), which permits unrestricted use, distribution, and reproduction in any medium, provided the original work is properly cited.
}

(Cox, 1982; Goode and Sasser, 1980), host resistance is considered the most economically and ecologically reliable method for control of bacterial spot disease in pepper plants (Hibberd et al., 1989). Five hypersensitive resistance (HR) genes, namely $B s_{1}, B s_{2}, B s_{3}, B s_{4}$ and $B s_{7}$, have been reported in pepper plant accessions PI163192, PI260535, PI271322, PI235047, and UENF1556, respectively (Cook and Guevara, 1984; Cook and Stall, 1963; Kim and Hartmann, 1985; Potnis et al., 2012), and two recessive genes, $b s_{5}$ and $b s_{6}$, that govern non-hypersensitive resistance and act additively with each other were also screened from PI271322 and PI163192, respectively (Jones et al., 2002; Vallejos et al., 2010). One or more of the HR genes have been transferred to the Early Calwonder (ECW) strain of the pepper plant to develop near isogenic lines for the respective genes, and the varieties developed were named ECW 10R, ECW 20R, ECW 30R and ECW 70R, depending on the respective HR gene incorporated, and as ECW 12346, with $B s_{1}, B s_{2}, B s_{3}, b s_{5}$ and $b s_{6}$ incorporated (Jones et al., 2002; Stall et al., 2009; Vallejos et al., 2010). Genetic control of bacterial spot disease by hypersensitive resistance genes has not been very successful due to the occurrence of pathogenic races that can overcome the HR genes (Cook and Stall, 1969; Hibberd et al., 1987b; Kousik and Ritchie, 1995; Sahin and Miller, 1995). The hypersensitive reaction of pepper plants is known to be induced by an interaction between the $B s$ genes in pepper plants and the corresponding effector (avirulence, $a v r B s$ ) genes in the pathogen in a gene-for-gene model (Minsavage et al., 1990; Potnis et al., 2012). Bacterial spot pathogens of peppers are classified into 11 pathotypes on the basis of interactions between the $B s_{1}, B s_{2}, B s_{3}$ and $B s_{4}$ genes that confer an HR reaction in the pepper and corresponding avirulence genes $\left(a v r B s_{1}, a v r B s_{2}, a v r B s_{3}\right.$ and $\left.a v r B s_{4}\right)$ in the pathogen (Stall et al., 2009). ECW 10R, ECW 20R, ECW 30R, and PI235047 (Capsicum pubescens) have been used as differential hosts in the classification of pathogen races (Sahin and Miller, 1998; Stall et al., 2009). In Korea, Kim et al. (2007) transferred $B s_{2}$ and $B s_{3}$ to a local Chilseong strain of 
Capsicum annuum, a susceptible cultivar grown in Yeongyang in Gyeongbuk province, and produced Chilbok-2 and Chilbok-3 for use as differential hosts.

In Korea, only race $\mathrm{P} 1$ and race $\mathrm{P} 3$ had been found (Kim, et al., 1990; Lee and Cho, 1996; Pae et al., 1994) until the 1990s. These races have been subdivided into races P1 and $\mathrm{P} 7$, and races $\mathrm{P} 3$ and $\mathrm{P} 8$, respectively, based on their abilities to elicit HR reactions in pepper strain PI235047 in the USA (Sahin and Miller, 1998; Stall et al., 2009). The prevalence of many races makes breeding and controlling the disease by resistant cultivars complicated. Therefore, a better understanding of the pathological races distributed in a given area, as well as host-pathogen relationships, is important in planning a breeding program for pepper plants for durable resistance to the disease. Here, we report results from testing Korean strains of Xanthomonas spp. infecting peppers to identify their pathotypes according to the race identification system (Stall et al., 2009).

The differential host sets consisting of Early Calwonder (ECW) and its isogenic lines ECW10R, ECW20R, and ECW30R, carrying $B s_{1}, B s_{2}$ and $B s_{3}$, respectively, and PI235047 with $B s_{4}$ gene, were kindly provided by USDA while Chilseong NILs, Chilbok-2, and Chilbok-3 were bred by us. All materials were sown in 200-cell trays with Wonjo mix (Nongkyung Agroindustrial Co., Ltd., Korea) and 16 plants of each line were transferred to 32 cell-trays one month after sowing in July 2012. In September 2012, the plants were transferred to pots $13 \mathrm{~cm}$ in diameter, again filled with Wonjo Mix, to grow more leaves.

Isolates of Xanthomonas spp. have been collected from various locations of Korea since the 1990s. These cultures have been maintained in water and on Yeast Extract Dextrose Calcium Carbonate (YDC) slants with routine subculture. Dry specimens of the collected leaves have also been stored in the refrigerator. In 2012, additional isolates were collected in the Chungnam, Jeonbuk and Jeonnam area of Korea. Overall, 67 isolates, 42, 3, 6, 3, 8 and 5 of which were originally collected from Daegu and Gyeongbuk, Chungnam, Chungbuk, Gangwon, Jeonnam and Jeonbuk province, respectively, were tested to determine their pathological races in September 2012. The confirmation study was conducted only with ECW NILs and PI235047 after transplanting the differential host plants to $25 \mathrm{~cm}$ pots in January 2013.

Isolates of pathogenic Xanthomonas spp., stored as stocks strains, were subcultured on yeast extract dextrose calcium carbonate (YDC) agar plates and incubated for $2-3$ days at $28-29^{\circ} \mathrm{C}$ to obtain pure cultures. Two-dayold, typical round, convex, mucoid, and yellow colonies were suspended in distilled water with a sterile cotton swab

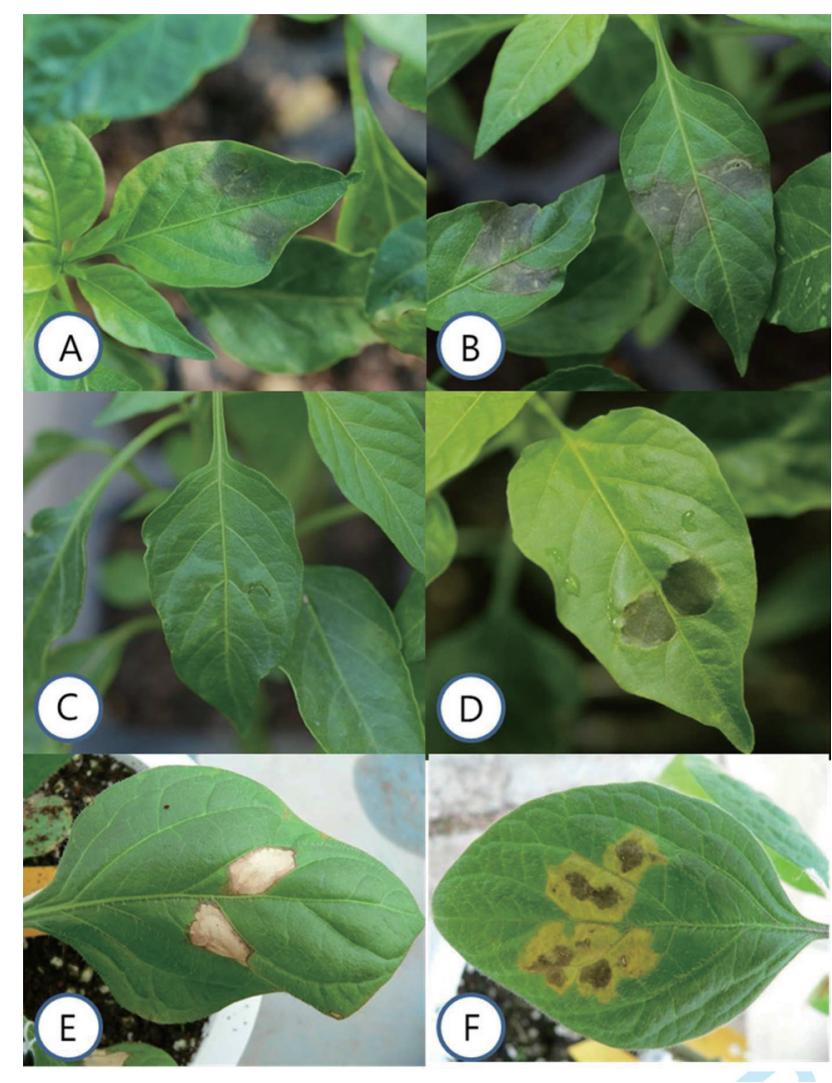

Fig. 1. Hypersensitive (HR) and susceptible (Sus) reaction to infiltration of bacterial spot pathogen. Hypersensitive reaction $24 \mathrm{~h}$ (A) and $48 \mathrm{~h}$, (B) post infiltration; susceptible reaction $48 \mathrm{~h}$, (C) and $72 \mathrm{~h}$, (D) post infiltration showing wet clear lesion with water-soaked margin. HR lesions on PI235047 carrying Bs4 gene formed in reaction to race $\mathrm{P} 1$ and $\mathrm{P} 3$, (E) and non-hypersensitive reaction to race $\mathrm{P} 7$ and $\mathrm{P} 8$, (F) 1 week post infiltration.

to obtain a suspension. The bacterial concentration was adjusted to approximately $10^{8} \mathrm{cfu} / \mathrm{ml}(0.2 \mathrm{OD}$ at $470 \mathrm{~nm})$ using a spectrophotometer (Kim, 1983). The bacterial suspension was infiltrated into the abaxial surface of the leaves on each side of the midrib using a syringe with the needle removed. Two leaves were used as replication for each isolate.

Races were determined on the basis of hypersensitive (HR) and susceptible (Sus) reactions in response to infiltration of the bacterial suspension into leaf tissues, according to the race identification system reported by Stall et al. (2009). A hypersensitive reaction was recognized by tissue collapse at the infiltration site, with the tissue turning from dark green to light black within $24-48 \mathrm{~h}$ post inoculation, while a susceptible or non-hypersensitive reaction by water-soaked lesions appearing 3 or 4 days post infiltration. HR lesions turned tan to papery white with light twisting while non-HR lesions spread with yellow margins with 
Table 1. Reaction of differential hosts for identification of pathotypes to isolates of bacterial spot pathogen infecting pepper plants in Korea

\begin{tabular}{|c|c|c|c|c|c|c|c|}
\hline \multirow{2}{*}{$\begin{array}{l}\text { Pathotype } \\
\text { (Avirulence gene) }\end{array}$} & \multirow[b]{2}{*}{ Isolate number } & \multirow{2}{*}{$\begin{array}{l}\text { No. of } \\
\text { Isolates } \\
(\%)\end{array}$} & \multicolumn{5}{|c|}{ Differential host with respective resistance gene } \\
\hline & & & ECW & $\begin{array}{l}\text { ECW10R } \\
(B s l)\end{array}$ & $\begin{array}{l}\text { ECW20R } \\
\quad(B s 2)\end{array}$ & $\begin{array}{c}\text { ECW30R } \\
(B s 3)\end{array}$ & $\begin{array}{l}\mathrm{PI} 235047 \\
\quad(B s 4)\end{array}$ \\
\hline $\begin{array}{l}\mathrm{P} 1 \\
\left(a v r B s_{2},\right. \\
\left.a v r B s_{3}, a v r B s_{4}\right)\end{array}$ & $\begin{array}{l}1-1,1-2,17,22,23,25,26,27 \\
38,39,041,48,49,51,63,64 \\
65,66,67,68,69,70,71,72,74 \\
75,76,77,78\end{array}$ & $\begin{array}{c}29 \\
(43.3)\end{array}$ & Sus $^{\mathrm{a}}$ & Sus & $\mathrm{HR}^{\mathrm{a}}$ & HR & HR \\
\hline $\begin{array}{l}\mathrm{P} 3 \\
\left(a v r B s_{2}, a v r B s_{4}\right)\end{array}$ & $15,28,45$ & $\begin{array}{c}3 \\
(4.5) \\
\end{array}$ & Sus & Sus & HR & Sus & HR \\
\hline $\begin{array}{l}\mathrm{P} 7 \\
\left(a v r B s_{2}, a v r B s_{3}\right)\end{array}$ & $\begin{array}{l}2,6,10,12-1,12-2,14,36,43 \\
46,47,50,51,52,53-1,53-2 \\
56,58,73,79,80,81,82\end{array}$ & $\begin{array}{c}23 \\
(34.3)\end{array}$ & Sus & Sus & HR & HR & Sus \\
\hline \multirow[t]{2}{*}{$\begin{array}{l}\mathrm{P} 8 \\
\left(a v r B s_{2}\right)\end{array}$} & $\begin{array}{l}5,6,7,8,13,18,30,032,42,57 \\
61,62\end{array}$ & $\begin{array}{c}12 \\
(17.9)\end{array}$ & Sus & Sus & HR & Sus & Sus \\
\hline & Total & 67 & & & & & \\
\hline
\end{tabular}

${ }^{\mathrm{a}} \mathrm{HR}=$ hypersensitive reaction characterized by rapid tissue collapse at infiltration site within $48 \mathrm{~h}$ post infiltration of the pathogenic bacterium; Sus $=$ susceptible reaction characterized by water-soaked or yellow lesions appearing $72 \mathrm{~h}$ or later post infiltration (Fig. 1).

time. Infiltration sites on tender leaves of susceptible plants often turned wet clear with water-soaking and yellowing margins (Fig. 1).

The reactions of the differential hosts to the 67 isolates collected from the six provinces of Korea are given in Table 1. Chilbok-2 and Chilobok-3 carrying $B s_{2}$ and $B s_{3}$, respectively, were included in the test but their reactions were the same as ECW 20R and ECW 30R, respectively, therefore, not listed here. Races P1, P3, P7, and P8 were found in the six provinces of Korea. Among the 67 isolates, $29(43.3 .0 \%)$ were race $\mathrm{P} 1,3(4.5 \%)$ were race $\mathrm{P} 3,23$ (34.3\%) were race $\mathrm{P} 7$, and $12(17.9 \%)$ were race $\mathrm{P} 8$. The races appeared to be evenly distributed in the six provinces although the number of isolates collected was limited and concentrated in Daegu and Gyeongbuk province. Races P7 and $\mathrm{P} 8$ have been subdivided from races $\mathrm{P} 1$ and $\mathrm{P} 3$, respectively, on the basis of their abilities to elicit an HR reaction in PI235047 carrying the Bs4 gene (Sahin and Miller, 1998; Stall et al., 2009). Thus, race P1 was found to be predominant in Korea, followed by race P7, and races P3 and P8 were also identified (Table 1). To date, races P4, P5, P6, $\mathrm{P} 9$ and $\mathrm{P} 10$ that can overcome the $B s_{2}$ gene have not been found in Korea. ECW 20R, ECW 12346, and Chilbok-2 carrying $\mathrm{Bs}_{2}$ gene exhibited hypersensitive resistance to all strains collected in Korea. However, ECW 10R, carrying $B s_{1}$, was susceptible to all isolates tested, indicating that races $\mathrm{P} 0, \mathrm{P} 2$ and $\mathrm{P} 5$ are not present in Korea, and ECW 30R and Chilbok-3 plants, carrying the $B s_{3}$ gene only, were resistant to races $\mathrm{P} 1$ and $\mathrm{P} 7$ only. In the 1990 s, only races P1 and P3 were reported in Korea (Kim et al., 1990; Lee and Cho, 1996; Pae et al., 1996). Thus, the pathotype distribution in Korea has been essentially unchanged for the last 15 years, although races P7 and P8 could be differentiated from race $\mathrm{P} 1$ and $\mathrm{P} 3$, respectively, according to their ability to induce HR reactions in PI235047 carrying the Bs4 gene. Regarding the relative frequency of pathotypes, Kim et al. (1990) and Lee and Cho (1996) reported that race P3 was detected more frequently than race $\mathrm{P} 1$, while Pae et al. (1994) reported that races 1 and 3 were found at a similar frequency. In the present study, however, the majority of the 67 isolates identified were race P1 (43.3\%), followed by race $\mathrm{P} 7$ (34.3\%). Race $\mathrm{P} 1$ and race $\mathrm{P} 7$ are formerly race 1 . Thus, the relative frequencies of pathotypes found in this study differed from the previously reported results. The discrepancy in the frequency of pathotypes may be due to the different collection sites of the studies, since races P1 and P3 can be observed in the same field and even in the same leaf (Kim et al., 1990). Pohronezny et al. (1992) reported a sudden shift in the predominant race from P2 to P1 in Southern Florida, and Kousik and Ritchie (1996) also reported a rapid shift from race $\mathrm{P} 1$ to race $\mathrm{P} 2$ to race $\mathrm{P} 3$ in North Carolina, due to the inactivation of effector genes (avrBs 1, avrBs 2 and $a v r B s 3$ ) in the pathogen by various mutations, including insertion elements. Likewise, a shift from race $\mathrm{P} 3$ to race $\mathrm{P} 1$ could have happened in Korea as reported by $\mathrm{Oh}$ et al. (2011). However, resistant varieties of 
pepper plants carrying any of the HR genes have not been distributed for cultivation in Korea. Selection pressure for a race shift, therefore, has not been present in Korea. The difference in the frequency of the races is more likely due to a difference in collection sites, since all strains that were newly isolated for this study from the Chungnam, Jeonbuk, and Jeonnam areas in 2012 were either P1 or P7. Thus, the hypersensitive resistance gene, $B s_{2}$, is still functioning in Korea and may be used in breeding for resistance. The validity of $B s_{1}$ and $B s_{3}$, for resistance, however, is over in Korea (Kim et al., 2009). In breeding for resistance, the exploitation of quantitative resistance not specific to races or the integration of the major HR genes with quantitative resistance would be desirable for more durable resistance (Hibberd, 1989; Jones et al., 2002; Stall et al., 2009; Vallejos et al., 2010). Substantial genetic diversity has been found among Korean strains of the bacterial spot pathogen (Chung et al., 1997). Abundant sources of non-hypersensitive resistance have also been reported (Kim et al., 2009; Sowell, 1960; Sowell and Dempsey, 1977; Tran and Kim, 2007) and are available at hand. Most of the sources of resistance are in hot chili type peppers in horticultural characters including fruit shape. Therefore, these sources of resistance may be more readily available for breeding Korean chili peppers, the most common type of pepper grown in Korea, than for breeding bell type peppers. In the current classification system of bacterial spot pathogen affecting peppers, bacterial spot disease may be caused by one of four species, including $X$. euvesicatoria, $X$. vesicatoria, $X$. gardneri, and $X$. perforans, or by any mixture of these variants (Jones et al., 2004, 2005; Stall et al., 2009). The association of pathotypes with the four species of Xanthomonas has not yet been reported, but this information would be useful to breed peppers resistant to bacterial spot disease.

\section{Acknowledgment}

This research was supported by Basic Science Research Program through the National Research Foundation of Korea (NRF) funded by the Ministry of Education (2013R1A1A2008630), and by a grant (710001-07-06) from the Agriculture, Food and Rural Affairs Research Center Support Program, Ministry of Agriculture, Food and Rural Affairs.

\section{References}

Chung, H. J., Kim, G. Y., Koh, Y. J., Nou, I. S. and Hwang, B. K. 1997. Genetic differentiation of strains of Xanthomonas campestris pv. vesicatoria by random amplified polymorphic
DNA (RAPD). Kor. J. Plant Pathol. 13:5-12.

Cook, A. A. and Stall, R. E. 1969. Differentiation of pathotypes among isolates of Xanthomonas vesicatoria. Plant Dis. Rep. 53:617-619.

Cook, A. A. and Guevara, Y. G. 1984. Hypersensitivity in Capsicum chacoense to race 1 of the bacterial spot pathogen of pepper. Plant Dis. 68:329-330.

Cook, A. A. and Stall, R. E. 1963. Inheritance of resistance in pepper to bacterial spot. Phytopathology 53:1060-1062.

Cox, R. S. 1982. Control of bacterial spot of tomato in southern Florida. Plant Dis. 66:870.

Goode, M. J. and Sasser, M. 1980. Prevention-the key to controlling bacterial spot and bacterial speck of tomato. Plant Dis. 64:831-834.

Hamza, A. A., Robène-Soustrade, I., Jouen, E., Gagnevin, L., Lefeuvre, P., Chiroleu, F. and Pruvost, O. 2010. Genetic and pathological diversity among Xanthomonas strains responsible for bacterial spot on tomato and pepper in the southwest Indian Ocean region. Plant Dis. 94:993-999.

Hibberd, A. M., Bassett, M. J. and Stall, R. E. 1987a. Allelism tests of 3 dominant genes for hypersensitive resistance to bacterial spot of pepper. Phytopathology 77:1304-1307.

Hibberd, A. M., Persley, D. M., Nahrund, G. C. and Gillespie, G. 1989. Breeding disease resistant Capsicum for wide adaptation. Acta Hort. 247:171-174.

Hibberd, A. M., Stall, R. E. and Bassett, M. J. 1987b. Different phenotypes associated with incompatible races and resistance genes in bacterial spot disease of pepper. Plant Dis. 71:10751078 .

Jones, J. B., Lacy, G. H., Bouzar, H., Minsavage, G. V., Stall, R. E. and Schaad, N. W. 2005. Bacterial spot-worldwide distribution, importance and review. Acta Hort. 695:27-31.

Jones, J. B., Lacy, G. H., Bouzar, H., Stall, R. E. and Schaad, N. W. 2004. Reclassification of the Xathomonads associated with bacterial spot disease of tomato and pepper. System. Appl. Microbiol. 27:755-762.

Jones, J. B., Minsavage, G. V., Roberts, P. D., Johnson, R. R. and Kousik, C. S. 2002. A non-hypersensitive resistance in pepper to the bacterial spot pathogen is associated with two recessive genes. Phytopathology 92:273-277.

Kim, B. S. 1983. Inheritance of resistance to bacterial spot (Xanthomonas campestris pv. vesicatoria (Doidge) Dye in peppers (Capsicum spp.). Ph. D. dissertation, University of Hawaii.

Kim, B. S. and Hartmann, R. W. 1985. Inheritance of a gene (Bs3) conferring hypersensitive resistance to Xanthomonas campestris pv. vesicatoria in pepper (Capsicum annuum). Plant Dis. 69:233-235.

Kim, B. S., Kwon, Y. S. and Hur, J. M. 1990. Differentiation and distribution of pathotypes of Xanthomonas campestris pv. vesicatoria pathogenic on pepper in Korea. Korean J. Plant. Pathol. 6:245-249.

Kim, B. S., Kim, Y. C., Shin, K. S. and Kim, J. H. 2007. Nearisogenic lines for genes conferring hypersensitive resistance to bacterial spot in chili pepper. Plant Pathol. J. 23:155-166. 
Kim, B. S., Souvinmonh, B., Son, K., Ahn, J. H. and Lee, S. M. 2009. New additions to sources of resistance to bacterial spot and field performance of HR gene NILs in Capsicum pepper. Hort. Environ. Biotech. 50:566-570.

Kousik, C. S. and Ritchie, D. F. 1995. Isolation of pepper races 4 and 5 of Xantnomonas campestris pv. vesicatoria from diseased peppers in southern U.S. fields. Plant Dis. 79:540.

Kousik, C. S. and Ritchie, D. F. 1996. Race shift in Xanthomonas camperstris pv. vesicatoria within a season in field-grown pepper. Phytopathology 86:952-953.

Lee, S. D. and Cho, Y. S. 1996. Copper resistance and race distribution of Xanthomonas campestris pv. vesicatoria on pepper in Korea. Kor. J. Plant Pathol. 12:150-155.

Minsavage, G. V., Dahlbeck, D., Whalen, M. C., Kearney, B., Bonas, U., Staskawicz, B. J. and Stall, R. E. 1990. Genefor-gene relationships specifying disease resistance in Xanthomonas campestris pv. vesicatoria - pepper interactions. Mol. Plant-Microbe Interact. 3:41-47.

Oh, C.-S., Lee, S. and Heu, S. 2011. Genetic diversity of avrBslike genes in three different Xanthomonas species isolated in Korea. Plant Pathol. J. 27:26-32.

Pae, D. H., Yoon, J. Y. and Lee, J. M. 1994. Pathotype distribution of Xanthomonas campestris pv. vesicatoria on pepper (Capsicum annuum) in Korea and cross-protection between the pathotypes. J. Kor. Soc. Hort. Sci. 35:126-130.

Pohronezny, K., Stall, R. E., Canteros, B. I., Kegley, M., Datnoff, L. E. and Ubramanya, R. 1992. Sudden shift in the prevalent race of Xanthomonas campestris pv. vesicatoria in pepper fields in southern Florida. Plant Dis. 76:118-120.

Potnis, N., Minsavage, G., Smith, J. K., Hurlbert, J. C., Nor- man, D., Rodrigues, R., Stall, R. E. and Jones, J. B. 2012. Avirulence proteins AvrBs7 from Xanthomonas gardneri and AvrBs1.1 from Xanthomonas euvesicatoria contribute to a novel gene-for-gene interaction in pepper. Mol. PlantMicrobe Interact. 25:307-320.

Sahin, F. and Miller, S. A. 1995. First report of pepper race 6 of Xanthomonas campestris pv. vesicatoria, causal agent of bacterial spot of pepper. Plant Dis. 79:1188.

Sahin, F. and Miller, S. A. 1996. Characterization of Ohio strains of Xanthomonas campesrtis pv. vesicatoria, causal agent of bacterial spot of pepper. Plant Dis. 80:773-778.

Sahin, F. and Miller, S. A. 1998. Resistance in Capsicum pubescens to Xanthomonas campestris pv. vesicatoria pepper race 6 . Plant Dis. 82:794-799.

Sowell, G. Jr. 1960. Bacterial spot resistance of introduced peppers. Plant Dis. Rep. 44:587-590.

Sowell, G. Jr. and Dempsey, A. H. 1977. Additional sources of resistance to bacterial spot of pepper. Plant Dis. Rep. 61:684686.

Stall, R. E., Jones, J. B. and Minsavage, G. V. 2009. Durability of resistance in tomato and pepper to Xanthomonads causing bacterial spot. Annu. Rev. Phytopathol. 47:265-284.

Tran, N. H. and Kim, B. S. 2007. Search for sources of resistance to bacterial spot (Xanthomonas campestris pv. vesicatoria) in Capsicum pepper. Acta Hort. 760:323-328.

Vallejos, C. E., Jones, V., Stall, R. E., Jones, J. B., Minsavage, G. V., Shultz, D. C., Rodrigues, R., Olsen, L. E. and Mazourek, M. 2010. Characterization of two recessive genes controlling resistance to all races of bacterial spot in peppers. Theor. Appl. Genet. 121:37-46. 